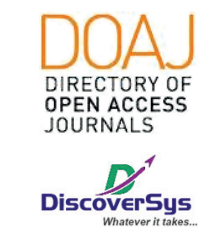

Published by DiscoverSys

\section{Gambaran faktor risiko penyebab terjadinya celah bibir dan celah langitan di Denpasar tahun 2019}

\author{
Kadek Tia Indah Purwitasari, ${ }^{1}$ I Gusti Putu Hendra Sanjaya, ${ }^{2}$ \\ Agus Roy Rusly Hariantana Hamid ${ }^{2 *}$
}

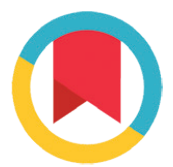

CrossMark

\title{
ABSTRACT
}

Background: Cleft lips and cleft palate are congenital abnormalities in the form of clefts that occur due to the lips or palate that are not fully integrated or developing separately. Factors causing cleft lips are a multifactorial combination of genetic factors and environmental factors. In Indonesia, the patients of cleft lips and cleft palate increase of 7,500 people per year. This study aims to determine the description of risk factors causing cleft lips and cleft palate in Denpasar 2019.

Methods: The research was conducted by a descriptive method using a cross-sectional approach. Samples were selected from the populationbased on inclusion and exclusion criteria. This study was conducted to obtain the risk factors causing cleft lips and cleft palate based on a genetic factor, a drug used, smoking, alcohol, pregnancy disorders, chemicals, nutrition, history of antenatal care, obesity and diabetes, parent's age, economic status, and infant's gender. Data were analyzed using SPSS software version 22.

Results: The results showed that cases of cleft lips and cleft palate in Denpasar 2019 based on genetic factor is 24,0\%, drug used (34\%), smoking history (52\%), no history of alcohol consumption, pregnancy disorders (28\%), chemicals exposure (18\%), do not get additional nutrition (42\%), didn't take any antenatal care (26\%), obesity and diabetes (4\%), the most parent's age in pregnancy are productive age group (60\%), majority low economic families status (60\%), and infant's gender dominated by the male (66\%).

Conclusion: This finding is useful because it can provide insight into the description of the risk factors causing cleft lips and cleft palate in Denpasar 2019. Further analytic research is needed to find the relationship between various risk factor variables.

Keywords: Cleft Lips, Cleft Palate, Genetic Factor, Risks.

Cite This Article: Purwitasari, K.T.I., Sanjaya, I.G.P.H., Hamid, A.R.R.H. 2020. Gambaran faktor risiko penyebab terjadinya celah bibir dan celah langitan di Denpasar tahun 2019. Intisari Sains Medis 11(2): 697-701. D0I: 10.15562/ism.v11i2.656

\section{ABSTRAK}

'Program Studi Sarjana Kedokteran dan Profesi Dokter, Fakultas Kedokteran, Universitas Udayana, Bali, Indonesia

${ }^{2}$ Sub Divisi Bedah Plastik, Rekonstruksi dan Estetik, Departemen Ilmu Bedah, Fakultas Kedokteran, Universitas Udayana, Bali, Indonesia

*Korespondensi: Agus Roy Rusly Hariantana Hamid, Sub Divisi Bedah Plastik, Rekonstruksi dan Estetik, Departemen IImu Bedah, Fakultas Kedokteran, Universitas Udayana, Bali, Indonesia;

royruslyhamid@yahoo.com

Diterima: $02-11-2019$

Disetujui: $16-06-2020$

Diterbitkan: 01-08-2020
Latar Belakang: Celah bibir dan celah langitan merupakan kelainan kongenital berupa celah yang terjadi akibat bibir atau atap mulut tidak sepenuhnya menyatu atau berkembang secara terpisah. Faktor penyebab celah bibir adalah kombinasi multifaktor baik itu faktor genetik dan faktor lingkungan. Di Indonesia penderita kelainan celah bibir dan celah langitan bertambah rata-rata 7.500 orang per tahun dan terus meningkat. Penelitian ini bertujuan untuk mengetahui gambaran faktor risiko penyebab terjadinya celah bibir dan celah langitan di Denpasar tahun 2019. Metode: Penelitian dilakukan dengan metode deskriptif menggunakan pendekatan potong lintang. Sampel dipilih dari populasi berdasarkan kriteria inklusi dan eksklusi. Penelitian dilakukan untuk memperoleh gambaran faktor risiko penyebab terjadinya celah bibir dan celah langitan berdasarkan faktor genetik, penggunaan obat-obatan, merokok, alkohol, gangguan kehamilan, zat kimia, nutrisi, riwayat antenatal care, obesitas dan diabetes, usia orang tua, status ekonomi, dan jenis kelamin bayi. Data dianalisis menggunakan software SPSS versi 22.
Hasil: Hasil penelitian menunjukkan kasus celah bibir dan celah langitan di Denpasar tahun 2019 berdasar faktor keturunan sebesar $24,0 \%$, penggunaan obat-obatan $(34,0 \%)$, riwayat merokok $(52,0 \%)$, tidak ada riwayat alkohol, gangguan kehamilan $(28,0 \%)$, paparan zat kimia $(18,0 \%)$, tidak mendapat nutrisi $(42,0 \%)$, tidak melakukan antenatal care $(26,0 \%)$, obesitas dan diabetes $(4,0 \%)$, usia orang tua saat kehamilan terbanyak pada kelompok usia produktif $(60,0 \%)$, status ekonomi mayoritas status keluarga ekonomi rendah $(60,0 \%)$, jenis kelamin bayi dengan kejadian celah bibir dan celah langitan di dominasi oleh jenis kelamin laki-laki $(66,0 \%)$.

Kesimpulan: Temuan ini bermanfaat karena dapat memberikan wawasan mengenai gambaran faktor risiko penyebab terjadinya celah bibir dan celah langitan di Denpasar tahun 2019. Perlu dilakukan penelitian analitik lebih lanjut guna mencari hubungan antara berbagai variabel faktor risiko. 


\section{PENDAHULUAN}

Celah bibir dan celah langitan merupakan kelainan kongenital berupa celah mulai dari bibir bagian atas hingga gusi, rahang, dan langitan yang tidak sepenuhnya menyatu atau berkembang secara terpisah sehingga tidak terbentuknya mesoderm pada daerah tersebut, serta prosesus nasalis dan maksilaris yang telah menyatu menjadi pecah kembali saat trimester pertama perkembangan janin. ${ }^{1}$ Celah dapat terjadi pada satu sisi (unilateral) maupun dua sisi (bilateral) secara simetris dan asimetris serta dapat meluas ke dasar lubang hidung (komplit) atau dengan lubang hidung yang masih intak (inkomplit). ${ }^{2}$

Celah bibir dan celah langitan secara umum lebih sering terjadi pada laki-laki yaitu sebesar $65 \%$ daripada wanita melalui 1/700 kelahiran. ${ }^{3}$ Angka kejadian kasus kelainan ini di Indonesia bertambah rata-rata 7.500 orang per tahun. ${ }^{4}$ Pertumbuhan dan perkembangan bibir secara normal terjadi pada minggu ke 5 hingga minggu ke 10 kehamilan. ${ }^{4}$ Celah dapat terjadi akibat tidak terjadinya penggabungan mesoderm dengan prosesus nasalis media akibat kegagalan mesoderm untuk penetrasi ke dalam groove dan tidak terjadi penetrasi oleh masenkim dengan epitel diantara prosesus nasalis medial dan lateral sehingga tidak akan terbentuk fusi menyebabkan epitel akan terpisah dan terbentuk celah. ${ }^{2}$

Secara umum, celah bibir dan celah langitan terjadi karena adanya gangguan saat pembentukan dan perkembangan embrio pada bagian orofasial. Gangguan tersebut terjadi melalui kombinasi multifaktor dari faktor genetik atau keturunan dan lingkungan. ${ }^{5}$ Faktor genetik dapat diturunkan secara langsung melalui orang tua dengan kelainan serupa, secara tidak langsung melalui orang tua normal tetapi pembawa gen abnormal atau carrier, dan diturunkan dari kelainan yang dimiliki oleh garis keturunan ayah atau orang tua laki-laki. ${ }^{6}$ Faktor lingkungan didapat dari faktor risiko ibu dan faktor risiko janin. ${ }^{6}$

Penggunaan obat-obatan diluar suplemen kehamilan yang didapat secara bebas diluar resep dokter maupun indikasi medis tertentu seperti anti konvulsan, anti emesis, dan kortikosteroid serta jamu-jamuan. ${ }^{78}$ Riwayat merokok, konsumsi alkohol, gangguan kehamilan, paparan zat kimia seperti pabrik, pembuatan cat dan pengrajin anyaman kayu, nutrisi masa kehamilan, riwayat antenatal care, obesitas dan diabetes, usia orang tua, dan status ekonomi serta jenis kelamin bayi juga diketahui sebagai faktor risiko janin. ${ }^{9}$

Tingginya kejadian celah bibir dan celah langitan di Indonesia dibutuhkan upaya penelitian besar difokuskan untuk pencegahan dan penatalaksanaan yang tepat pada kasus. Informasi yang tersedia mengenai faktor risiko penyebab terjadinya celah bibir dan celah langitan belum diketahui dengan baik. Oleh karena itu, penelitian ini bertujuan untuk mengetahui gambaran faktor risiko penyebab terjadinya celah bibir dan celah langitan di Denpasar tahun 2019.

\section{METODE}

Penelitian ini merupakan penelitian deskriptif cross-sectional yang dimaksudkan untuk mengetahui gambaran faktor risiko penyebab terjadinya celah bibir dan celah langitan di Denpasar tahun 2019. Penelitian dilaksanakan selama 6 bulan (April 2019-September 2019), dengan variabel penelitian: faktor keturunan, penggunaan obat-obatan, riwayat merokok, konsumsi alkohol, gangguan kehamilan, paparan zat kimia, nutrisi masa kehamilan, riwayat antenatal care, obesitas dan diabetes, usia orang tua, dan status ekonomi serta jenis kelamin bayi. Sampel pada penelitian ini adalah data primer yang didapat melalui kuesioner, dengan besar sampel sama dengan 50 responden. Kriteria inklusi dari penelitian ini data kuesioner pasien semua usia yang telah didiagnosis mengalami celah bibir dan celah langitan di Denpasar. Sedangkan, kriteria eksklusi penelitian ini adalah data kuesioner pasien celah bibir dan celah langitan yang tidak bersedia menjadi sampel. Data dikumpulkan dan dianalisis univariat dengan menggunakan perangkat lunak SPSS versi 22 untuk Windows.

\section{HASIL}

Hasil penelitian menunjukkan bahwa terdapat beberapa faktor resiko yang tinggi secara persentase terhadap terjadinya celah bibir dan celah langitan di Denpasar tahun 2019 (Tabel 1). Sebagian besar responden penelitian yang memiliki celah bibir dan celah langitan diketahui tidak memiliki faktor keturunan $(76,0 \%)$, tidak terdapat riwayat penggunaan obat-obatan (66,0\%), memiliki kebiasaan merokok (52,0\%), tidak ada riwayat konsumsi alkohol (100,0\%), maupun tidak ada gangguan kehamilan $(72,0 \%)$ (Tabel 1). Penelitian ini juga menunjukkan bahwa sebagian besar responden tidak memiliki riwayat paparan terhadap zat kimia $(82,0 \%)$ maupun riwayat obesitas dan diabetes $(96,0 \%)$, akan tetapi sebagian besar responden penelitian memiliki kaitan dengan faktor nutrisi $(58,0 \%)$, riwayat ANC $(74,0 \%)$, dan berjenis kelamin laki-laki (66,0\%) (Tabel 1).

Disamping itu, hasil penelitian ini juga menunjukkan bahwa berdasarkan status ekonomi, sebagian besar responden memiliki status ekonomi 
rendah $(60,0 \%)$, diikuti dengan status ekonomi menengah $(36,0 \%)$, dan tinggi $(4,0 \%)$. Sedangkan berdasarkan usia orang tua, kejadian celah bibir dan celah langitan secara proporsi lebih tinggi pada orang tua berusia $21-35$ tahun $(60,0 \%)$, dikuti

\section{Tabel 1 Gambaran faktor risiko penyebab terjadinya celah bibir dan celah langitan di Denpasar tahun 2019 berdasar faktor keturunan}

\begin{tabular}{|c|c|c|}
\hline Variabel Penelitian & Jumlah $(\mathrm{N}=50)$ & Persentase (\%) \\
\hline \multicolumn{3}{|l|}{ Faktor Keturunan } \\
\hline $\mathrm{Ya}$ & 12 & 24,0 \\
\hline Tidak & 38 & 76,0 \\
\hline \multicolumn{3}{|c|}{ Penggunaan obat-obatan } \\
\hline $\mathrm{Ya}$ & 17 & 34,0 \\
\hline Tidak & 33 & 66,0 \\
\hline \multicolumn{3}{|l|}{ Kebiasaan merokok } \\
\hline Ya & 26 & 52,0 \\
\hline Tidak & 24 & 48,0 \\
\hline \multicolumn{3}{|l|}{ Konsumsi alkohol } \\
\hline $\mathrm{Ya}$ & 0 & 0,0 \\
\hline Tidak & 50 & 100,0 \\
\hline \multicolumn{3}{|l|}{ Gangguan kehamilan } \\
\hline $\mathrm{Ya}$ & 14 & 28,0 \\
\hline Tidak & 36 & 72,0 \\
\hline \multicolumn{3}{|l|}{ Paparan zat kimia } \\
\hline $\mathrm{Ya}$ & 9 & 18,0 \\
\hline Tidak & 41 & 82,0 \\
\hline \multicolumn{3}{|l|}{ Faktor nutrisi } \\
\hline Ya & 29 & 58,0 \\
\hline Tidak & 21 & 42,0 \\
\hline \multicolumn{3}{|l|}{ Antenatal Care (ANC) } \\
\hline Ya & 37 & 74,0 \\
\hline Tidak & 13 & 26,0 \\
\hline \multicolumn{3}{|l|}{ Obesitas dan diabetes } \\
\hline $\mathrm{Ya}$ & 2 & 4,0 \\
\hline Tidak & 48 & 96,0 \\
\hline \multicolumn{3}{|l|}{ Usia orang tua } \\
\hline$<20$ tahun & 1 & 2,0 \\
\hline 21-35 tahun & 30 & 60,0 \\
\hline$>35$ tahun & 19 & 38,0 \\
\hline \multicolumn{3}{|l|}{ Status Ekonomi } \\
\hline Rendah & 30 & 60,0 \\
\hline Menengah & 18 & 36,0 \\
\hline Tinggi & 2 & 4,0 \\
\hline \multicolumn{3}{|l|}{ Jenis kelamin } \\
\hline Laki-laki & 33 & 66,0 \\
\hline Perempuan & 17 & 34,0 \\
\hline
\end{tabular}

dengan usia $>35$ tahun $(38,0 \%)$, dan $<21$ tahun $(2,0 \%)$ (Tabel 1).

\section{PEMBAHASAN}

Berdasarkan hasil penelitian, gambaran faktor risiko penyebab terjadinya celah bibir dan celah langitan berdasar faktor keturunan sebesar 12 orang $(24,0 \%)$. Menurut studi yang dilakukan oleh Manuaba IBG, kelainan berdasar keturunan didapat genetik dan mutasi kromosom melalui keluarga yang berdekatan. ${ }^{10}$ Faktor genetik dapat diturunkan dari garis keturunan ayah dan atau ibu akibat adanya gen yang abnormal. ${ }^{10}$ Kelainan kongenital dapat terjadi karena perubahan materi genetik hanya dari 1 gen yang rusak atau hilang dan kesalahan pada susunan kromosom saat pembentukan sel telur atau sel sperma. ${ }^{11}$

Gambaran faktor risiko penyebab terjadinya celah bibir dan celah langitan berdasar penggunaan obat-obatan sebesar 17 orang (34,0\%). Berdasarkan kepustakaan, beberapa obat-obatan maupun jamu yang di konsumsi pada saat kehamilan dapat menimbulkan gangguan kongenital termasuk celah bibir dan celah langitan. ${ }^{12}$ Hal ini dikarenakan sifat teratogenik atau disformik akibat obat yang melintasi plasenta mengalami biotransformasi menimbulkan senyawa teratogenik asam lemah yang akan mengubah $\mathrm{pH}$ pada sel embrio sehingga dapat menghambat pertumbuhan dan perkembangan embrio saat proses organogenesis maupun pematangan fungsi organ. ${ }^{12}$

Gambaran faktor risiko penyebab terjadinya celah bibir dan celah langitan berdasar merokok aktif maupun pasif sebesar 26 orang $(53,0 \%)$. Merokok dapat menyebabkan celah bibir pada janin yang dikandungnya karena kandungan zat racun pada perokok pasif lebih tinggi dibandingkan perokok aktif, rokok pada wanita menyebabkan berkurangnya kadar enzim GSTT1 (Glutathione $S$ Transferase Theta-1) yang dapat membantu proses organogenesis. ${ }^{13,14}$ Tidak ditemukan sampel dengan riwayat pengonsumsian alkohol selama kehamilan, ini dapat terjadi karena faktor lain yang mempengaruhinya. ${ }^{14}$

Faktor risiko penyebab terjadinya celah bibir dan celah langitan berdasar gangguan kehamilan sebesar 14 orang (28\%). Ibu dengan gangguan pada kehamilan mengindikasikan terjadinya suatu infeksi tertentu yang dapat mengganggu proses pertumbuhan organ terutama saat trimester pertama kehamilan yang bisa mengganggu seluruh proses organogenesis. ${ }^{10}$ Gambaran faktor risiko penyebab terjadinya celah bibir dan celah langitan berdasar zat kimia sebesar 9 orang (18\%). Paparan zat kimia pada saat kehamilan dapat menyebabkan keracunan kronis yang meningkatkan kejadian karsinogenik, 
mutagenik, dan teratogenik yang dapat menimbulkan kelainan kongenital pada bayi termasuk celah bibir. ${ }^{15}$ Semakin sering dan lama paparan zat kimia menyebabkan zat kimia terakumulasi lebih banyak di dalam tubuh ibu selama kehamilan melalui kulit, hidung, dan mulut yang semakin mengganggu pertumbuhan janin pada proses organogenesis. ${ }^{15}$

Hasil penelitian menunjukkan faktor risiko penyebab terjadinya celah bibir dan celah langitan berdasar nutrisi sebesar 21 orang (42\%) tidak mendapat nutrisi pada saat kehamilan. Tidak mendapat zat penting terutama asam folat selama kehamilan dapat menimbulkan kelainan kongenital terutama pada saat pembentukan organ karena asam folat berperan dalam pembentukan sistem saraf, pembentukan tulang, regulasi hormon, dan pusat kecerdasan. ${ }^{10}$

Gambaran faktor risiko penyebab terjadinya celah bibir dan celah langitan berdasar riwayat antenatal care sebesar 13 orang (26\%) tidak melakukan antenatal care. Kunjungan antenatal care yang kurang atau tidak sama sekali dapat menyebabkan terjadinya kelainan seperti celah bibir dan langitan, hal ini terjadi karena pemeriksaan rutin masa kehamilan membantu ibu dalam mencegah terjadinya gangguan pada kehamilan melalui monitoring ketat, pemberian edukasi dan suplemen kehamilan serta mempersiapkan ibu menghadapi kelahiran dan masa nifas. ${ }^{16}$

Gambaran faktor risiko penyebab terjadinya celah bibir dan celah langitan berdasar obesitas dan diabetes sebesar 2 orang (4\%). Kondisi hiperglikemia dan hiperinsulinemia pada kehamilan akan memacu terjadinya metabolisme yang memerlukan kadar oksigen lebih tinggi, tetapi plasenta bayi memiliki keterbatasan untuk transpor oksigen yang dapat menyebabkan hipoksia janin. ${ }^{17}$ Hipoksia akibat keadaan hiperglikemia janin akan mengganggu proses organogenesis karena tidak adanya asupan kadar oksigen yang cukup sebagai sumber energi metabolik. ${ }^{17}$

Gambaran faktor risiko penyebab terjadinya celah bibir dan celah langitan berdasar usia orang tua didapatkan usia 21-35 tahun merupakan usia tersering ibu melahirkan bayi dengan celah bibir dan langitan yaitu sebesar 30 orang (60\%). Hal ini tidak sebanding dengan literatur yang menyatakan usia dibawah 21 tahun dan diatas 35 tahun lebih berisiko melahirkan bayi dengan kejadian celah bibir dan celah langitan..$^{18}$ Berdasar literatur, usia 21-35 tahun mentalnya masih mudah mengalami ketidakstabilan yang dapat mempengaruhi perhatian ibu terhadap asupan nutisi dan kondisi kesehatan lainnya selama kehamilan sehingga perkembangan janin tidak optimal. ${ }^{18}$

Gambaran faktor risiko penyebab terjadinya celah bibir dan celah langitan berdasar status ekonomi didapatkan mayoritas status ekonomi keluarga rendah sebesar 30 orang (60\%). Berdasar literatur, status ekonomi yang rendah mengakibatkan keterbatasan dalam penyediaan pangan, asupan nutrisi yang tidak baik dan kesadaran untuk melakukan antenatal care yang kurang atau tidak sama sekali sebagai peranan penting saat proses organogenesis janin. ${ }^{19}$ Status ekonomi rendah termasuk pendidikan rendah menyebabkan kurangnya pemahaman kesehatan pada kehamilan. ${ }^{19}$

Gambaran faktor risiko penyebab terjadinya celah bibir dan celah langitan berdasar jenis kelamin bayi didapatkan distribusi terbanyak yaitu pada jenis kelamin laki-laki sebesar 33 orang (66\%). Hal ini sesuai dengan penelitian yang dilakukan Loho JN dan Supandi A et al., menyatakan celah bibir dan celah langitan lebih sering terjadi pada laki-laki dari pada perempuan karena vaskularisasi bayi laki-laki terjadi lebih lambat., ${ }^{420}$

\section{SIMPULAN}

Berdasarkan hasil penelitian gambaran faktor risiko penyebab terjadinya celah bibir dan celah langitan di Denpasar tahun 2019 yang telah memenuhi syarat inklusi, diperoleh simpulan faktor risiko penyebab terjadinya celah bibir dan celah langitan di Denpasar tahun 2019 adalah kombinasi dari faktor keturunan atau genetik dan faktor lingkungan (multifaktor). Sebagian besar responden penelitian diketahui tidak memiliki faktor keturunan, tidak terdapat riwayat penggunaan obat-obatan. memiliki kebiasaan merokok, tidak ada riwayat konsumsi alkohol, tidak ada gangguan kehamilan, tidak memiliki riwayat paparan terhadap zat kimia, maupun riwayat obesitas dan diabetes. Hasil penelitian ini diharapkan dapat bermanfaat bagi klinisi dalam memberikan upaya untuk mencegah terjadinya kejadian celah bibir dan celah langitan pada neonatus dengan membantu calon orang tua agar mendapat edukasi mengenai hal yang wajib di persiapkan dan dilakukan untuk mendapatkan bayi yang dilahirkan sehat. Penelitian analitik lebih lanjut diperlukan guna mencari hubungan antara setiap faktor risiko.

\section{KONFLIK KEPENTINGAN}

Tidak terdapat konflik kepentingan dalam penyusunan laporan penelitian ini.

\section{PERSETUJUAN ETIK}

Penelitian ini telah mendapatkan ijin dari Komisi Etik Penelitian Fakultas Kedokteran Universitas Udayana dengan Keterangan Kelaikan Etik (Ethical 
Clearance) Nomor: 915/UN14.2.2.VII.14/LP/2019 tertanggal 01 April 2019.

\section{PENDANAAN}

Tidak ada.

\section{KONTRIBUSI PENULIS}

Seluruh penulis memiliki kontribusi yang sama terhadap penulisan laporan penelitian ini baik dari tahap penyusunan kerangka konsep, pengumpulan data, analisis data penelitian, hingga interpretasi data penelitian dalam bentuk publikasi.

\section{DAFTAR PUSTAKA}

1. Worley ML, Patel KG, Kilpatrick LA. Cleft Lip and Palate. Clin Perinatol. 2018;45(4):661-678.

2. Resnick CM, Estroff JA, Kooiman TD, Calabrese CE, Koudstaal MJ, Padwa BL. Pathogenesis of Cleft Palate in Robin Sequence: Observations from Prenatal Magnetic Resonance Imaging. J Oral Maxillofac Surg. 2018;76(5): 1058-1064.

3. Yilmaz HN, Özbilen EÖ, Üstün T. The Prevalence of Cleft Lip and Palate Patients: A Single-Center Experience for 17 Years. Turk J Orthod. 2019;32(3):139-144.

4. Supandi A, Monoarfa A, Oley MH. Angka Kejadian Celah Bibir di Rsup Prof. Dr. R. D. Kandou Manado periode 2011-2013. Jurnal E-Clinic (ECL). 2014;2(2):1-7.

5. Yu W, Serrano M, Miguel SS, Ruest LB, Svoboda KK. Cleft lip and palate genetics and application in early embryological development. Indian J Plast Surg. 2009;42 Suppl(Suppl):S35-S50.

6. Yilmaz HN, Özbilen EÖ, Üstün T. The Prevalence of Cleft Lip and Palate Patients: A Single-Center Experience for 17 Years. Turk J Orthod. 2019;32(3):139-144.

7. Rezaallah B, Lewis DJ, Zeilhofer HF, Berg BI. Risk of Cleft Lip and/or Palate Associated With Antiepileptic Drugs: Postmarketing Safety Signal Detection and Evaluation of Information Presented to Prescribers and Patients. Ther Innov Regul Sci. 2019;53(1):110-119.

8. Munsie JW, Lin S, Browne ML, Campbell KA, Caton AR, Bell EM, et al. Maternal bronchodilator use and the risk of orofacial clefts. Hum Reprod. 2011;26(11):3147-3154.
9. Acuña-González G, Medina-Solís CE, Maupomé G, Escoffie-Ramirez R, Hernandoz-Romano J, MarquezCorona MDL, et al. Family history and socioeconomic risk factors for non-syndromic cleft lip and palate: a matched case-control study in a less developed country. Biomedica. 2011;31(3):381-391.

10. Manuaba IBG. Ilmu Kebidanan, Penyakit Kandungan, dan KB untuk Pendidikan Bidan. Edisi 2 Jakarta: EGC. 2012.

11. Yunani, Bustami A, Angelina C. Faktor Kelainan Kongenital pada Bayi Baru Lahir di Ruang Perinatologi Rumah Sakit Abdul Moeloek Bandar Lampung 2015. Jurnal Dunia Kesmas 2016;5(2):74-83.

12. Kawalec A, Nelke K, Pawlas K, Gerber H. Risk factors involved in orofacial cleft predisposition - review. Open Med (Wars). 2015;10(1):163-175.

13. Lammer EJ, Shaw GM, Iovannisci DM, Finnell RH. Maternal smoking, genetic variation of glutathione s-transferases, and risk for orofacial clefts. Epidemiology. 2005;16(5):698-701.

14. Maidartati, Parsaulian P. Gambaran Pengetahuan Ibu Hamil Trimester I tentang Pengaruh Rokok terhadap Tumbuh Kembang Janin di Polikandungan RSUD Kota Bandung. Jurnal Ilmu Keperawatan. 2015;3(1):38-50.

15. Polii EG, Wilar R, Umboh A. Faktor risiko yang berhubungan dengan kejadian kelainan bawaan pada neonatus di RSUP Prof Dr. R. D. Kandou Manado. Jurnal E-Clinic (ECl), 2016;4(2):1-8

16. Radityo AN, Kosim MS, Budhi RK, Irawan G, Rini AE. Faktor Risiko Kelainan Kongenital Orofacial pada Neonatus. Media Medika Muda. 2016;1(1):1-6.

17. Kozma A, Radoi V, Ursu R, Bohaltea CL, Lazarescu H, Carniciu S. GESTATIONAL Diabetes Mellitus and The Development of Cleft Lip/Palate in Newborns. Acta Endocrinol (Buchar). 2019;-5(1):118-122.

18. Bille C, Skytthe A, Vach W, Knudsen LB, Andersen AMN, Murray JC, et al. Parent's age and the risk of oral clefts. Epidemiology. 2005;16(3):311-316.

19. Makbruri. Faktor Risiko Yang Memengaruhi Berat Badan Lahir Rendah Dan Sangat Rendah Di Kecamatan Seberang Ulu II Kota Palembang Periode 1 Januari-31 Desember 2008. Gradien: Jurnal Ilmiah MIPA. 2015;11(1):1079-84.

20. Loho JL. Prevelensi labioschisis di RSUP Prof.Dr.R.D. Kandou Manado periode Januari 2011 - Oktober 2012. Jurnal e-Biomedik (eBM): 2013; 1(1):396-401.

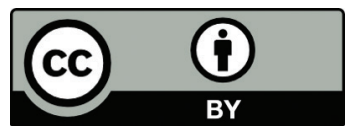

This work is licensed under a Creative Commons Attribution 